Socio-technical imaginary of the fourth industrial revolution and its implications for vocational education and training: a literature review

\author{
Pre-publication version Journal of Vocational education and training \\ doi.org/10.1080/13636820.2018.1498907
}

\author{
James Avis \\ HudCres \\ School of Education and \\ Professional development \\ University of Huddersfield \\ Email: j.avis@hud.ac.uk
}




\title{
Socio-technical imaginary of the fourth industrial revolution and its implications for vocational education and training: a literature review
}

\begin{abstract}
This literature review engages with a diverse and sometimes contradictory body of work, employing an analytic stance rooted in policy scholarship. It discusses rhetorical constructions of the Fourth Industrial Revolution $\left(4^{\text {th }} I R\right)$, locating these in understandings of the economy rooted in a neo-liberalism which rests upon a capitalist terrain. The $4^{\text {th }} I R$ is an ideological construct which reflects specific material interests and has particular implications for education and training. The $4^{\text {th }}{ }^{\prime} R^{\prime}$ s association with digitalisation and artificial intelligence is ambivalent. For some writers this leads to technological unemployment whilst for others, even though there is labour market disruption, there is no employment crisis that cannot be resolved. The strong connection between the $4^{\text {th }} I R$ and labour market requirements are softened by those writers who adopt a qualitative analysis of advanced manufacturing work. These scholars suggest the relationship between technology and skill is rather more complex than the protagonists of technological unemployment describe. Neo-Marxist writers develop a qualitatively different account of the current conjuncture to the imaginary of the $4^{\text {th }}$ IR. In this instance the analysis turns towards the elimination of labour from paid employment, together with the falling rate of profit and bypasses the former arguments. This review concludes by arguing that technology and artificial intelligence are entwined with social relations, being sites of class struggle. How this is played out is an outcome of the balance of power, not only within the social formation but globally. How far the development of the forces of production are compatible with capitalist relations is a moot point, as this is also a site of struggle. The paper draws out the implications for VET and considers progressive educational responses. However, such a practice needs to be set within a broader politics that is committed to the development of a socially just society.
\end{abstract}

Key words: literature review, Industrie 4.0, The fourth Industrial revolution, Vocational Education and training, neo-liberalism, capitalism, socio-technical imaginary 


\section{Socio-technical imaginary of the fourth industrial revolution and its implications for vocational education and training: a literature review}

This review seeks to unpack conceptualisations of the $4^{\text {th }}$ Industrial Revolution $\left(4^{\text {th }} / \mathrm{R}\right)$ and its German equivalent Industrie 4.0. It examines the relationship of these notions to neo-liberal capitalism and future imaginaries of economic and social life. As such it explores the $4^{\text {th }} I R$ as an ideological and rhetorical construction which is intimately connected to digitalisation, robotisation, the salience of artificial intelligence as well as the development of smart factories in which machine are linked to one another both within a particular factory and across sites of production. These terms are thought to bear significantly upon the labour market and the labour process as well as, by default, vocational education and training (VET) systems. The paper concludes by addressing the significance of these arguments for progressive VET.

I have described this paper as a literature review and think that this warrants some discussion. I have drawn on a wide ranging literature which I have referenced extensively, by doing so I hope to offer the reader a resource upon which they may draw. The paper represents a particular type of literature review, one that seeks to engage with debates in the field. This is not a systematic or definitive literature review based upon the protocols of the former which rests upon a quasi-technicist and positivist approach to empirical research (but see Avis, 2003; EPPI Centre, n.d.; Maclure, 2005; Oakley, 2002). Rather it addresses the particular and often contradictory stances that have been taken towards the $4^{\text {th }}$ IR and the resulting debates. Inevitably I am positioned as a participant in these discussions having selected the particular themes and debates to be examined. I have not limited my review to advanced manufacturing as to have done so would have restricted the argument and have ignored the ideological ramifications of the term and its social imaginary. I have aimed to mobilise a range of arguments that can rest alongside and have an affinity with the $4^{\text {th }}$ IR. The $4^{\text {th }}$ IR encompasses far more than a narrow technical focus upon advanced manufacturing. Consequently, I engage, albeit briefly, with arguments that address post-work, Marxism as well as Italian Workerism as these provide something of a counter to more mainstream arguments that address the $4^{\text {th }}$ IR. These analyses provide a rather different understandings of the ideological and socio-economic context in which the $4^{\text {th }}$ IR is placed.

This literature review is structured in the following manner. Initially it seeks to explore the term $4^{\text {th }}$ IR and its socio-technical imaginary as well as its ideological manifestations. The literature suggests that the $4^{\text {th }}$ IR is set within a particular trajectory lodged within neo-liberal understandings of the economy. This trajectory is contrasted with those found in a literature that addresses the current socio-economic context/conjuncture. This is followed by a discussion of literature that addresses robotisation, artificial intelligence and employment, which then leads into a consideration of the labour market and the $4^{\text {th }}$ IR. I then draw on a body of work that offers a qualitatively different analysis of the socio- 
economic context to that found in discussions of the $4^{\text {th }}$ IR. In these sections the capitalist labour process, work and alienation as well as post-work are examined. Finally, I address the implications that flow from the preceding for VET.

Starting Points: Industrie 4.0 and the Fourth Industrial Revolution

Pfeiffer (2017) draws our attention to the relationship between Industrie 4.0 and the $4^{\text {th }}$ IR. The former term was popularised by three German Engineers at an Industrial fair in Hannover in 2011. Prior to the fair Industrie 4.0 was mainly seen as a technical term concerned with the organisation of industrial production and in particular advanced manufacturing. The $4^{\text {th } I R}$ and Industrie 4.0 are terms that are often used interchangeably and have now assumed more rhetorical and ideological resonances, exemplified in Klaus Schwab's (2017) The Fourth Industrial Revolution. Schwab is the founder and executive chairman of the World Economic Forum. In a somewhat conventional manner he describes the four industrial revolutions in a way that is resonant with presentations found in economic and social history texts books.

Figure 1. Industrial Revolutions
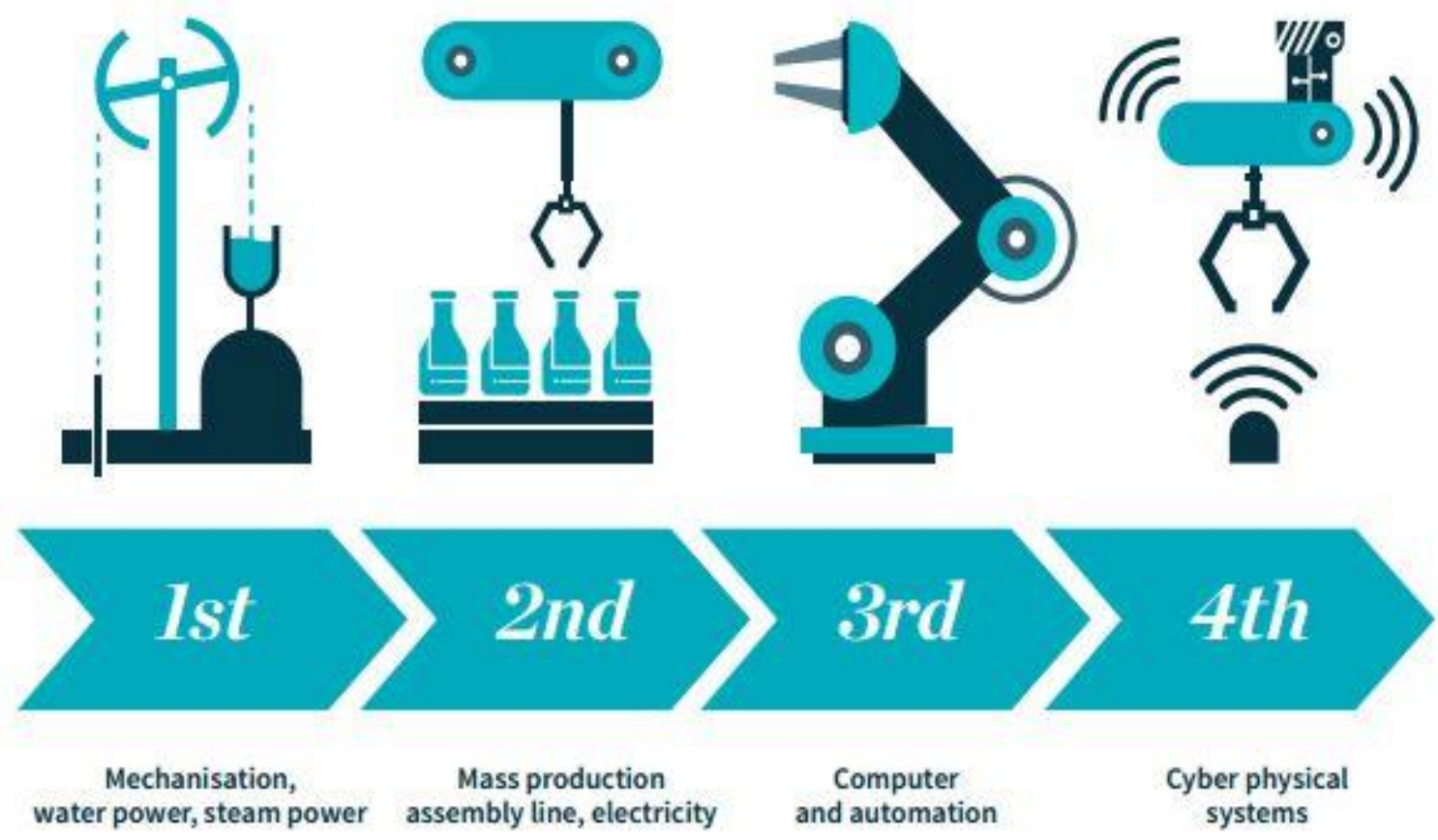

source: N8 Research Partnership, 2016 Creative Commons

Insert figure 1 about here

In numerous reports, we encounter diagrams that are similar to the above which embody a linear trajectory leading from the first to the $4^{\text {th }}$ IR and that implicitly follow a technological if not determinist logic (Fuchs, 2018; Peters, 2017:3; Kagermann, Wahlster and Helbig, 2013:13; Wahlster, 2016:4; Schrauf and Berttram 2016:8). This trajectory is set within a particular periodicy with the $1^{\text {st }}$ IR running from 1760 to around 1840 and related to the 
development of the railways, steam power and mechanical production. The $2^{\text {nd }} I R$ running from late nineteenth to the early/mid-twentieth century, marked by the development of mass production and electrification (Peters, 2017:3). The $3^{\text {rd }} I R$ is thought to anticipate the $4^{\text {th }}$ with the emergence of computers, digitalisation and the internet. The $4^{\text {th }}$ IR by intensifying the features of the $3^{\text {rd }}$ is thought to lead to the development of a qualitatively different socio-economic context. This rests with an argument that embodies a number of elements that are taken to be self-evidentially the case. Schwab (2017) for example describes the $4^{\text {th }}$ IR as,

enabling "smart factories"... creating a world in which virtual and physical systems of manufacturing globally cooperate with each other in a flexible way. This enables the absolute customization of products and the creation of new operating models...

It is the fusion of these technologies [gene sequencing, nanotechnology, quantum computing, etc] and their interaction across the physical, digital and biological domains that make the fourth industrial revolution fundamentally different from previous revolutions. $(7,8)$

The $4^{\text {th }} \mathrm{IR}$ is almost presented in neutral terms as a societal development that has to be managed for the benefit of all. Underpinning the arguments is the suggestion that the move to the $4^{\text {th }}$ IR reflects a historical trajectory that is in some senses inevitable (Fuchs, 2018). Pfeiffer (2017) describes this, drawing on Adams and Groves (2007), as a case of a future to be told, tamed, and traded. By these terms she has in mind the manner in which a discourse or imaginary is constructed around the $4^{\text {th }}$ IR. A discourse which is reflected in Schwab's writings as well as in much of the literature produced not only by the state but also by policy institutes and management consultants (Citi GPS, 2016; MGI, 2013, 2017; Frey and Osborne, 2013). In this way the $4^{\text {th }}$ IR becomes a future that is told and constructed but it is one in which the velocity and rapidity of change brings in its wake a series of disruptions that are potentially destabilising and need to be tamed or managed (Oschinski and Wyonch, 2017). At the same time this discourse constitutes a future to be traded and invested in. There are several points I would like to make concerned with the ideological ramifications of the discussion thus far, by drawing on the notion of socio-technical imaginary (Jasanoff 2015a, b), its relation to neo-liberal capitalism as well as its periodicy.

Socio-Technical Imaginary: The Fourth Industrial Revolution

Jasanoff (2015: 4) suggests that socio-technical imaginaries are:

Collectively held, institutionally stabilized, and publically performed visions of desirable futures, animated by shared understandings of forms of social life and social order attainable through, and supportive of advances in science and technology.

Those who promulgate notions of the $4^{\text {th }} \mathrm{IR}$ are at one and the same time constructing and reconstituting a particular understanding of the future and importantly its imagining. This is 
often an iterative and circular process with the same argument being reproduced in a range of policy documents as well as those produced by consultancy firms. Consequently, we encounter a number of recurring themes, robotisation, artificial intelligence, digitalisation, smart factories, interoperability, interconnectivity, nanotechnology and so on (Hajkowicz, Reeson, Rudd, et al, 2016; Bloem, van Doorn, Duivestein, et al, 2014). Such notions seep into popular culture and media representations but also draw upon science fiction, from 'Metropolis' to 'Star Trek'. Channel 4, a British television channel, in 2017 had a Rise of the Robots season, which explored driverless cars and artificial intelligence as well as sex bots, with BBC channel 3 presenting a programme entitled 'can robots love?'. Whilst these latter illustrations are somewhat trite they anticipate fundamental societal change which impact upon social relations, building upon the transformative power of technology and that exaggerate the potentiality of artificial intelligence (Chollet, 2017). In this way they contribute to the formation of a sociotechnical imaginary.

Importantly, the imaginaries that swirl around the $4^{\text {th }}$ IR acknowledge a range of contradictory tensions that either, intensify current trends or are thought to emerge in the future. Such tensions include:

- the polarisation of jobs allied with that of income and we might add wealth (Citi GPS, 2016; Goos and Manning, 2007; Goos, Manning and Salomons, 2014; Autor 2015);

- a shift in favour of capital away from labour (Lordon, 2014:40);

- monopolisation (Harvey, 2014);

- technical unemployment set against labour shortages (Citi GPS, 2016; Pew Research Centre, 2017);

- demographic changes benefitting either older or younger workers (Goodhart and Pradhan, 2017; MGI. 2017);

- deskilling and/or upskilling (Alhammadi, 2014);

- a surplus population excluded from waged labour (Avent, 2017);

- the growth of precariousness (Standing, 2016);

- ecological despoilation (Hajkowicz et al 2016);

- or indeed any combination of the above (Dolphin, 2015).

As can be seen there are tensions and contradictions between these issues. However, within this sociotechnical imaginary there is the promise that difficulties can be managed and in that sense overcome (for a wry look at these issues see YouTube 2014 Australians for Coal). Whilst the discourse emphasises the transformative power of technology it is in effect domesticated, its potential is framed to sit within a particular, and one might suggest, neoliberal or at least capitalist project.

Importantly, studies in science and technology remind us that there is a dialectical relationship between technology and social relations (Jasanoff and Kim, 2015; and see Avis 
1981). Social relations inform the development of science and technology whilst simultaneously science and technology impact upon social relations - we could describe this as co-constitution. The point is we cannot think of technology as being outside of the social relations in which it is embedded. Mazzucato (2013) illustrates the manner in which the US state and its funding of research has contributed to the development of innovative products and much the same could be said about the military industrial complex (Mowery, 2010). We need only to think about the development of the internet, personal computing, and nanotechnology. In many ways the state and its funding of research has been crucial for capitalist development. Mazzucato (2013:88) suggests that the state rather than being a brake on innovation has been pivotal. She argues that "Far from stifling innovation and being a weight to the system, [the state] has fostered innovation and dynamism in many industries, with the private sector often taking a back seat" (and see Mazzucato, 2013, chapter 4, 75-90 and, Mazzucato and Perez, 2014). The state, at least in recent history, has been less risk averse than has capital.

The $4^{\text {th }}$ IR imaginary is rooted in a neo-liberal and capitalist logic. It takes for granted key tenets of capitalism, the necessity for growth, the importance of productivity, marketization, commodification as well as the pursuit of profit allied with a fundamental concern with competitiveness (see for example, Fuchs, 2018; Schwab, 2017). In other words, the endless pursuit of the accumulation of capital. At the same time this imaginary seeks to address the problems and difficulties that flow from neo-liberalism and its relationship to austerity - a brutalised form of capitalism. To reiterate, the imaginaries that surround the $4^{\text {th }}$ IR acknowledge a range of contradictory tensions that either intensify current trends or are thought to emerge in the future. Such a stance acknowledges that these relationships are subject to regional variation both within and across social formations. Yet at the same time it is important to acknowledge capitalism has several facets. Mention has already been made of the significance of the state for research and development which can result in the creation of innovative products. The capitalist state is also pivotal in seeking to create conditions that align with the long term interests of capital. It thereby aims to manage class conflict and struggle in a way that secures the wellbeing of capital (Fleming, 2017; Miliband, 1973; Poulantzas, 1978). This can be seen in the egalitarian capitalism (Kenworth, 2004) of Nordic countries following the end of the second world war. However, in recent years this has been challenged by a more abrasive neo-liberalism (See special issue European Education Research Journal, forthcoming). Much the same point could be made about Germany and processes of dualization and segmentation. The former term refers to the situation whereby core workers are covered by collective agreements set against an unorganised and unregulated periphery (Thelen, 2014: 13-14). The latter term points to a shift away from collectivism to segmentalism (Thelen and Busemeyer, 2008, 2011:69). In collectivism employers tended to over train their employees who developed portable skills whereas in segmentalism employees develop company specific skills tied to internal labour markets that may not necessarily be transferable. Such responses can be 
related to coalitions of interest, regional specificities, neo-liberalism as well as the balance of power between labour and capital. These processes, particularly in Germany, are set within a context in which the imaginary of industrie 4.0 is hegemonic.

One of the tensions surrounding the $4^{\text {th }}$ IR concerns worries over the consequences of the increasing polarisation of wealth allied to a concern with managing the contradictions of capitalism can be seen in the responses of many policy makers. For example, Carney (2014) the governor of the Bank of England, Legard (2014) the head of the IMF, Obama (2015) the former president of the US and May (2016) the UK's current prime minister and in any number of reports that call for a more inclusive form of capitalism. These interventions call for the need to rein in the excesses of particular sections of capital. Such arguments are also present in those forwarded by the apologists of capital, amongst whom we could include Schwab (2017), who seek to soften its excesses (Hutton, 2013, 2015; Sainsbury, 2013). There are at least two points to make. Firstly, these interventions can be seen as attempts by national and supranational bodies to secure the long term interests of capital. Secondly, these concerns are set within a framework that stresses competitive individualism. Although the global, national and regional distribution of wealth, and to a lesser extent income, are important sites of struggle, it is nevertheless important to recognise that capitalism has no particular interest in equality or wellbeing other than their contribution to the creation of surplus value and the accumulation of capital. There are however particular problems that arise in the current socio-economic context allied with the increasing significance of rentier capitalists who generate income from financial assets, intellectual property rights as well as from other forms of rent. In this instance money is used to acquire more money, the point is that such activities are somewhat parasitic and do not directly arise from or contribute to the productive economy (Frase, 2016:71-74; Standing, 2014:81-83).

\section{Trajectories and the Fourth Industrial Revolution, a contested field}

Earlier I described a particular trajectory followed by industrial revolutions, from the $1^{\text {st }}$ to the $4^{\text {th }}$. This is but one periodicy that could be set amongst a number of others. , For example, Brynjolfsson and McAfee (2014) describe the shift from the first to second machine age whilst other writers discuss a periodicy related to forms of capitalism. In this instance we encounter shifts from industrial capitalism towards late, cognitive and/or immaterial capitalism (Boutang, 2011; Gorz, 2010). In a not dissimilar fashion Engeström's (2010:191) model of historical modes of production develops the work of Victor and Boynton (1998:233). In this instance there is a long term shift away from craft production, to mass production, lean production, mass customisation, co-configuration and ultimately to social production. The final mode of production anticipates the socialisation of the means of production. Adler's paleo Marxism would construe the latter change in Engeström's (2010) model as indicative of outcomes derived from the contradiction between the forces and relations of production that portend societal transformation (Adler, 2006; Adler, P. \& Heckscher, 2006; and see Avis 2016:66-69). In more recent work Adler has discussed the evolution of organisational paradigms towards the network, whereby there are links across 
internal and external boundaries (Bodrožić and Adler, 2018:8). Each organisational paradigm seeks to overcome the difficulties encounter by earlier forms but which in turn generate their own contradictions, with the direction of change towards the 'socialization of production'. In this case the enterprise has access not only to other enterprises but also to other sources of expertise (Bodrožić and Adler, 2018:30). What these various trajectories have in common is that they seek to develop an understanding of the changes impacting upon wider society as well as work and organisational relations. They point towards what could be described as tendential processes as well as an acknowledgement of capital's endless search for new opportunities to accumulate capital and appropriate value - that is to say, make money. These models offer heuristic devices but should not be seen as necessarily indicative of sudden ruptures or breaks, in as much as there is a need to acknowledge uneven development and the presence of various modes of production within any social formation, albeit that one may be more dominant than the others. In some respects, the affordances offered by social production allied with digitalisation echo a reimagining of craft production whereby boundaries between organisation and wider sources of expertise become more porous. In their different ways these trajectories contribute towards the formation of socio-technical imaginaries that can be mobilised in counter hegemonic struggles. Or more specifically in Adler's (2006) paleo Marxism with its conceptualisation of 'socialization of production' together with Engeström (2010) notion of social production which offer progressive possibilities. However, such possibilities should not be conceived in deterministic or an evolutionary fashion but rather in relation to the balance of power between capital and labour, or in other words class struggle.

\section{Robotisation, Artificial Intelligence, Employment and the Fourth Industrial Revolution}

Any number of papers and books have argued that the growth of robotisation will have a profound impact on employment and will lead to the replacement of routine manual jobs by robots (Brynjolfsson and McAfee, 2011, 2014; Ford. 2016, Peters, 2017). In a much quoted paper Frey and Osborne $(2013: 21,22)$ write, citing a technical report produced by McKinsey Global Institute (MGI),

Estimates by MGI (2013) suggests that sophisticated algorithms could substitute for approximately 140 million full-time knowledge workers worldwide... The trend is clear: computers increasingly challenge human labour in a wide range of cognitive tasks.

Such trends, or so it is claimed, will lead to technological unemployment and be exacerbated by developments in artificial intelligence, the use of big data as well as the Internet of Things. In the latter case interconnected sensors within a particular factory, but also across supply chains, will automatically determine levels of production without human intervention. This is the spectre of 'smart' factories, fully automated systems which have no need for waged labour, that transfer data through the internet. There are at least two 
points to be raised. Firstly, as many authors have mentioned fears about the impact of technological change on employment are by no means new, having been expressed in the work of Marx (1976 [1867]), Braverman (1974) and many others (See, Anslow 2016). Importantly, we need to acknowledge that technology is never neutral but is entwined with social relations (Mishel and Shierholz, 2017). We can also think back to the Luddites (Bregman, 2016:75, 87-90; Sale, 1996), to Keynes' (2009) intervention in the 1930s as well as to the worries over automation and employment that were raised in the 1950/60s (Autor, 2015:3; Mokyr, Vickers and Ziebarth, 2015). Such worries have been shown to be misfounded (Teixeira, 2017). Secondly, Baxter et al (2012) and Pfeiffer $(2014,2016)$ have illustrated empirically the need for skilled labour to monitor and troubleshoot not only in advanced manufacturing but also in other automated processes (and see Saniter and Howe, 2017), for example, in piloting a plane, or in monitoring a chemical or nuclear plant. Skilled workers who formerly worked on machines that are now linked together through sensors will have a feel for the job. In Sennett's (2009) terms such workers will hold tacit knowledge, having a material consciousness of the manufacturing process. Intuitively, from the sound of the machines, vibrations and so on the worker will gain a sense of what is right and wrong and therefore the adjustments that need to be made. Much the same point could be made about a skilled car mechanic who may, rather than relying on computerised sensors, prefer to listen to the sound of the engine. As automation advances and increasingly covers a range of interconnections and as workers become progressively distanced from working on machines, to monitoring them, the level of skill rather than decreasing will increase in line with the complexity of the production process. A single worker may well be responsible for a number of interconnected machines whereas previously there would have been a one to one relationship. In order to troubleshoot the worker will require a sophisticated understanding of production. Baxter et al (2012:66) remind us of one of the ironies of automation whereby if a system frequently crashes operators will become skilled in responding to these routinely. However, systems that rarely trigger alarms will require higher levels of training to ensure operators respond appropriately. At the same time there is the danger of intense boredom leading to apathy of the kind Paulsen (2014) describes as a feature of empty labour and which might be exacerbated by advances in artificial intelligence. This applies particularly to those workers who have a strong sense of work obligation and find themselves in effect with little to do. It is also important not to exaggerate the impact of artificial intelligence. Chollet (2017) reminds us that the enactment of intelligence is socially situated and consequently is more sophisticated than computational power alone.

\section{The Labour Market and the Fourth Industrial Revolution}

There is a raft of work that addresses the relationship between levels of employment and automisation and digitialisation with much of this literature suggesting the growth of technological unemployment (Avent, 2017; Livingston, 2012; Ross, 2016:35-43). A far more cautious stance is adopted by labour economists who questions the assumption of technological unemployment. Goos and Manning (2007) suggest that since 1975 the UK labour market has evidenced job polarisation with increased employment characterising the highest and lowest waged occupations. A similar argument in relation to job polarisation in the US has been developed by Autor, Katz and Kearney (2006). Goos and Manning suggest 
that this is also a feature of the European labour market based on evidence drawn from 16 West European countries in the period 1993-2010 (Goos, Manning and Salomons, 2014). Job polarisation is a consequence of the hollowing out of the employment structure and the significance of non-routine service level jobs. Goos, Manning and Salomons argue, drawing upon Autor's work, that analyses based upon 'skill-biased technical change' can only take us so far in explaining these trends and that such arguments need to be allied with what they describe as Autor, Levy and Murnane's (2003), routinisation thesis. Writing in 2015 Autor (12) identifies two types of task that are difficult to computerise. Firstly, those that are characterised by problem solving, intuition, creativity and persuasion and secondly, nonroutine tasks involving situational adaptability, personal interaction and are features of occupations such as:

food preparation and serving jobs, cleaning and janitorial work, grounds cleaning and maintenance, in-person health assistance by home health aides, and numerous jobs in security and protective services.... While these activities are not highly skilled by the standards of the US labor market, they present daunting challenges for automation (12).

Processes of job polarisation are also related to the specificity of the particular labour market in which they are set. There are two points to make. For example, an increased demand for workers at the top of the income structure can be allied with an increased demand for particular types of service jobs, janitors, cleaners and so on, which whilst remaining low waged may nevertheless gain increased income compared with other similarly placed low waged workers. We could compare the features of the labour market found within the US rust belt with those of New York. In the later there will be a demand for service workers which will be depressed in the former. Secondly, many middling level jobs will have routine features that render them amenable to computerisation which results in the hollowing out of the occupational structure. However, we need to aware of the subtleties surrounding these debates, processes of job polarisation and substitution and need to address the question of which low waged or middle level occupation is being examined. The significance of low waged service workers has already been considered but much the same argument could be directed at middle-level occupations. Holzer (2015) suggests that many economists emphasise the role of digital technologies in hollowing out middle-skill jobs, as against this he argues that this process applies to some but not all such jobs. There are 'middle-skill' jobs that require post-secondary education in for example health care, mechanical maintenance and repair, that are not amenable to automation. In addition, in the case of some of these jobs employers find it difficult to recruit labour. This may be partly a consequences of the relatively low wages offered and the reluctance of employers to increase these as they fear this would reduce their competitiveness. Autor $(2015: 26)$ speculates that, 
Employment polarization will not continue indefinitely (as argued in Autor 2013).

While some of the tasks in many current middle-skill jobs are susceptible to automation, many middle-skill jobs will continue to demand a mixture of tasks from across the skill spectrum. For example, medical support occupations radiology technicians, phlebotomists, nurse technicians, and others - are a significant and rapidly growing category of relatively well-remunerated, middleskill employment.

The hollowing-out of middle-level jobs allied with the impact of digitialisation and robotisation upon routine level jobs has been associated with the growth in technical unemployment. Many labour economists doubt the veracity of this argument. To secure their claim they draw upon the history of employment from the Luddites to the present day. Haldane (2015:7) refers to the 'lump of labour' fallacy, the notion that technological change leads to increased levels of unemployment (for a not dissimilar argument see Atkinson and $\mathrm{Wu}, 2017)$. Haldane (2015) argues that one of the consequences of technology displacing labour is that goods and services become cheaper which then boosts demand for goods and services and the new industries that supply these which in turn leads to increased employment. He acknowledges that the balance between the loss of jobs as a result of technological substitution and compensatory processes leading to increased employment as result of the production of new goods and services, is an empirical question. He nevertheless argues that since 1750 the direction of travel has been counter to technological unemployment. Rather he argues (2015:9),

Viewed over the sweep of history, then, there is essentially no evidence to suggest technology has damaged jobs and plenty to suggest it has boosted wages. Technology has enriched labour, not immiserated it. Mill was right; Ricardo was wrong. Labour is not dead wood to be carved up between tasks. It is a tree whose trunk and branches have lengthened and thickened with time. The "lump of labour" fallacy is just that.

This is a stance shared by the Institute of Directors. Whilst technological innovation can disrupt labour markets it is suggested that claims of technology induced mass unemployment have been misplaced with more jobs being created than lost (Nevin, 2016:9). Mishel and Bivens (2017) endorse this argument drawing on Acemoglu and Restrepo's (2017a) analysis of the US economy. Similarly, Dittrich in a footnote (2016:6 footnote18) has challenged the belief that many well paid middle level jobs will be lost as a result automation, using as evidence a survey of German companies which found that these employers planned to hire more workers rather than reduce employment (Seeverband der Bayerischen Metall- und Elektro-Arbeitsgeber 2016). 
In many respects the previous arguments are convincing. The convictions of technological pessimists seem to be challenged by the optimists, that is, if we consider paid employment as a good in itself. Perhaps it would be salutary to recall Fleming's excoriation of much theoretical and applied economics that purveys a narrative "that defies the daily experience of the $99 \%$-ers as the backwash of debt, stress and insecurity threatens to drag us under" (2017:5).

There are however a number of issues that need to be addressed. Whilst historically technologically determined mass unemployment has not been a permanent feature of social formations in the west, it does not necessarily follow that this will be the case in the future (Autor, 2015:3). We cannot view the past unproblematically to predict the future. In addition, we need to consider the nature of employment, its relationship to capitalism and the wider global economy. For example, Rodrik (2016:2-3) has discussed 'premature deindustrialisation' in low and medium income economies. He is using this term to suggest that these societies are undergoing deindustrialisation at a much earlier point than the historical norm found within the advanced economies of the west. Consequently, these late industrialisers are unable to build large manufacturing sectors and deindustrialise at lower levels of income than those societies that industrialised at an earlier date. In addition, because of labour saving technologies in the advanced economies this opens up the possibility of reshoring production and the rebundling of processes that were formerly separate. This is facilitated in part by the Internet of Things with elements of production being automated through the use of the internet and sensors (Livesey, 2017; Whittaker, 2015:37).

\section{The Capitalist Labour Process and the Fourth Industrial Revolution}

What I want to do here is to address a somewhat different literature that rather than drawing on the work of labour economists, engages with neo-Marxist, sociological and critical analyses of waged labour. Whilst the broad outlines of these arguments align with those of labour economists in relation to the polarisation of jobs and income, the hollowing out of middle level occupations as well as the significance of precariousness, they adopt a more quizzical approach to waged labour (but on precariousness see Coyle, 2017). In many respects the arguments I address in this section run parallel with those concerned with digitalisation and the $4^{\text {th }}$ IR. Blacker suggests,

The current neoliberal mutation of capitalism has evolved beyond the days when the wholesale exploitation of labor under-wrote the world system's expansion. While "normal" business profits plummet and theft-by-finance-rises, capitalism now shifts into a mode of elimination that targets most of us - along with our environment - as waste products awaiting managed disposal. (Blacker, 2013:1)

The increased significance of rentier capitalism, whereby money is used to make more money from money, forms a backdrop to these ideas. Blacker has in mind, those black communities in the US located in areas of economic despoliation featuring closed factories 
and abandoned neighbourhoods (Roediger, 2017:2). Such processes can be mapped onto the European experience. For example, the north of England has higher rates of unemployment and levels of disadvantage than the south (Shildrick, MacDonald, Webster and Garthwaite, 2012) and the same could be said about East Germany in comparison with the West (Roberts, 2016). Importantly social geographers (Martin and Morrison, 2003) alert us to the constructed and spatial nature of labour markets with areas of disadvantage existing alongside skilled and high waged global labour markets. Thus within a social formation areas of full employment and putative skills gaps/mismatch may sit alongside regions/localities characterised by multiple disadvantage and the lack of decent jobs (Keep and James, 2012; Orr, 2016). The expulsion of workers from the formal economy has been a longstanding feature of the developing and emerging economies (Davies, 2006; Sassen, 2014). Embedded in the arguments of technological pessimists is a concern with unemployment and the expulsion from work. There are two points I would like to make, the first addresses the significance of waged labour and the second the notion of 'busy work' allied with surplus labour.

\section{Work Alienation and Capitalism and the Fourth Industrial Revolution}

For Marx through our labour we express our species being. But within capitalism this relation is distorted with capital appropriating the fruits of our labour. Yet at the same time waged labour is celebrated in capitalist societies and its loss carries with it a whole set of negative consequences for our wellbeing (Beckett, 2018; Wilkinson and Pickett, 2010; and see Srnicek and Williams, 2015:92-98). It is certainly the case that the loss of a wage can be devastating not only in terms of income but also with respect to a reason for living, health and status. It is important to place these very real experiences within their socio-economic setting as well as the ideological context in which they are placed. In some respects, these notions reflect the material relations in which we are located, whilst at the same time echoing petty-bourgeois sensitivities which interpellate us towards waged labour. Anderson, (2017:131-144) in her rejoinder to Cowen's (2017) response to her Princeton lectures, reminds us of the brutalities surrounding low waged work in contemporary neo-liberal America in which employees are subject to the arbitrary authority of managers/employers. To support her claims Anderson draws on the work of Ehrenreich (2002) who explored the lived experiences of those engaged in low waged work. In a number of respects Ehrenreich's qualitative study provides a corrective both to the work of labour economists and to those who stress the benefits of waged labour. There is a resonance here to the UK, with Goos and Manning (2007) referring to 'lousy' jobs and Keep and James (2012) commenting on 'rotten' jobs.

Coyle (2017:10) notes that "while the [UK] employment rate is at a record, real earnings growth has been slow, especially for unskilled workers". This is in part a consequence of the changing balance of power between labour and capital. In addition, Holzer (2015:5) reminds us that whilst employers bemoan skill shortages they may be unwilling to invest either in 
training or to increase wage levels for fear of undermining competitiveness. When unskilled labour is cheaper than the machines that could substitute for it, the former will be used. This results in the 'productivity paradox' whereby whilst there has been overall increased investment in IT this fails to deliver gains in productivity. Such an argument has a bearing upon the way in which we examine waged labour in the current conjuncture. When commentators argue that employment has reached new heights it is imperative to unpack such claims in relation to wages, the nature of the available work as well as the rhetoric of self-employment which has often been used as a gloss or second rate alternative to paid employment. The point is that the stance adopted by technological pessimists presumes a determinism which downplays the complexity and messiness of social processes and struggles that impact upon waged labour, as well as firms' competitive strategies (Acemoglu and Restrepo, 2017b). Such reflections lead to an examination of the arguments surrounding post-work, surplus labour and 'busy' work.

\section{Post-Work and the Fourth Industrial Revolution}

Much of the work I have previously cited refuses the suggestion that labour is being expelled from paid employment. This argument stands in direct opposition to those who adopt the reverse position, some of whom I consider in this section. There is a tension between those who experience and bemoan precariousness and intermittent employment and those for whom the whole of life seems to be centred around work (Ehrenreich, 2002; Fleming, 2014; Shildrick, et al, 2012). In the diagrammatic representations that reflect the imaginary of the $4^{\text {th }}$ IR (see my figure 1 , starting points $p 4-5$ ), as well as documents produced by business organisations and consultants, whilst there is reference to mass production there is virtually none to Fordism, Post-Fordism, industrial capitalism, or cognitive capitalism. On one level this is not particularly surprising given the sources I have drawn upon but the 'transition' from Fordism to Post-Fordism marks a very particular change in labour relations. It is also important to recognise the uneven development of these processes with earlier forms of employment relations sitting alongside the newer. Fordism featured mass production and consumption, a standardised production process and a detailed division of labour (Lordon, 2014:29-30). This can be set against Post-Fordism that emphasises the importance of flexibility, innovation and team work. In this respect PostFordist notions can be seen to be part of the same zeitgeist as the $4^{\text {th }} \mathrm{IR}$, in the sense that it heralds the transformation of the labour process and emphasises the importance of knowledge and adaptability (Avis, 1993). There are two other points to make. The first relates to Italian Workerism and the second to arguments that address jobless growth as well as what Rifkin (2014) refers to as zero marginal cost. In the preceding discussion of the $4^{\text {th }}$ IR and its social and technical imaginary the former's rootedness within capitalist social relations and neo-liberalism was addressed. However, in its ideological manifestation the $4^{\text {th }}$ IR is presented as an inevitable development flowing from the first to the current IR. What is silenced in these constructions is the manner in which the $4^{\text {th }}$ IR connects to the development of capitalism and its articulation with class struggle. Italian Workerism 
(Lotringer, 2004; Marazzi, 2011; Tronti, 2007) addresses this issue and argues that PostFordism was capital's response to class struggle and workers 'refusal to labour'. Lotringer writes: 'It was Italian workers' stubborn resistance to the Fordist rationalization of work ... that forced capital to make a leap into the Post-Fordist era of immaterial work' (2004:11). In part these processes alert us to the manner in which technology is entwined with social relations, with Holzer (2015) drawing our attention to capitalist strategies in relation to wages and the substitution of machines for labour.

Harvey (2014:104-111) argues that the logic of capital leads to the substitution of machines for living labour. In the short term, for a particular capitalist, this serves to maximise the accumulation of capital. This is the eliminatory logic that Blacker (2013) addresses. However, if this process is taken to its conclusion the result will be a crisis of profitability as it corrodes the price mechanism and leads to the tendency for profits to fall. For Harvey, as with other Marxists, social or what some describe as living labour, is the source of surplus value/profits. The competitive advantage gained by early adoption of advanced technology will become generalized and thereby serve to depress profitability. This in turn will result in the search for new markets. The privatisation of the welfare state is a case in point, as is the significance of financialisation. Rifkin (2014:2) points out that “Capitalism's raison d'être is to bring every aspect of human life into the economic arena, where it is transformed into a commodity to be exchanged as property in the market place". In the case of financialisation money in the form of rent is used to generate more money without engaging directly with production. Bodrožić and Adler's (2018) discussion of new organisational forms is relevant here, as are those that relatedly address 'platform' capitalism, which serve as an intermediary that networks different users through the internet (Srnicek, 2017). Bodrožić and Adler's (2018:8) describe the network as a new organisational paradigm that links and rationalises business processes across internal and external boundaries, leading to their redesign up and down the value chain. Such affordances derive from the mobilisation of digitalisation and the Internet of Things. In the latter case, the internet will be used to link automated processes and forward data within and across networks - features of the $4^{\text {th }}$ IR. In addition, there is a link with capital's endless search for new sources of profitability as manifest in 'platform' capitalism, whereby the management of data becomes a source of profitability. Srnicek (2017:43) describes platforms as 'digital infrastructure that enable two or more groups to interact'. They are 'intermediaries that bring together different users: customers, advertisers, service providers, producers, suppliers and even physical objects'. We need only think of Uber, Amazon and eBay as examples that have built upon the opportunities derived from the internet and digitalisation but which also have monopolistic tendencies. Srnicek (2017:45) refers to 'network effects' whereby the more users who engage with a particular platform the more valuable it becomes - in this instance we could think of Facebook. 
The second point to make relates to what Rifkin (2014) refers to as 'the zero marginal cost society'. Some years ago Leadbeater (1999) in his Living On Thin Air: A New Economy, celebrated the affordances provided by the internet in distributing knowledge (or more correctly information, see Moodie, 2016:111-6) at virtually zero marginal cost. This linked up with a discussion concerned with the development of free software through the open source movement. Such arguments are reflected in Benkler's (2006) discussion of peer-topeer production, the sharing economy and social production which derive from the affordances offered by the internet and the forms of collaborative labour involved in developing free software. Such notions are echoed in the work Aigrain (2012) and many others. Indeed, the developments that both Adler and Heckscher (2006), as well as Engeström (2006) anticipate are based upon the possibilities derived from digitalisation and the opportunities it provides for collaboration. Whilst I have no wish to enter into idle speculation about the long term development of the economy, I would like to make two points. Firstly, Rifkin (2014), along with other writers, seeks to generalise from the near zero cost of distributing knowledge on the internet to other sectors of the economy. Here he has in mind the production of green energy and products, with these processes being generalisable to advanced manufacturing - that is to say the promise of producing goods at near zero marginal cost. Secondly, such arguments morph into a discussion of post-scarcity which serves to challenge capitalist relations. The functioning of a capitalist economy is dependent on scarcity which is undermined in an economy marked by abundance. There is another way we could view these arguments. They could be considered as referring to tendential possibilities, or better still, as sites of contestation or struggle. Mason (2015:144) suggests the key contradiction facing contemporary capitalism lies "between the possibility of free, abundant socially produced goods, and a system of monopolies, banks and governments struggling to maintain control over power and information". A struggle in Mason's terms, over a post-capitalism whose precondition is abundance, which as a result "will deliver some form of social justice spontaneously (144)", as against a capitalism that has reached its limits and is struggling to maintain control. Whilst this argument might to some readers seem fanciful it serves to lead into a discussion of surplus labour, 'busy' work and post-work. I will then consider the significance of the arguments I have addressed in this paper for vocational education and training. Lest it be forgot the arguments with which I engage are those that swirl around the current socio-economic conditions and are set within the zeitgeist of a conjuncture in which the imaginary of the $4^{\text {th }}$ IR forms but a part. Srnicek (2017:37) comments that various terms have been used to describe this conjuncture from the $4^{\text {th }} I R$, to the gig economy, sharing economy, on-demand economy, the app economy and so on. The latter terms refer to the affordances offered by the internet for connectivity, flexibility and intermittent labour that address a particular task.

There is a paradox. Discussions of surplus labour are set within a context in which labour economists suggest that to the extent this arises, it is a consequence of the skills gap rather than a secular feature of the economy. In addition, at least in the UK, rates of employment 
are claimed to be at an all-time high following the financial crisis of 2008. At the same time growth in the earnings of unskilled workers has been slow (Coyle, 2017:10). This by default reflects the significance of underemployment and over qualification whereby the latter are underused in waged labour. Rather than reprise these arguments I want to address the relationship between surplus labour and 'busy' work.

Holzer, (2015) Fleming (2017) and by default Coyle (2017) have discussed the competition between dead labour, embodied in fixed capital, and living labour and for Holzer this limits the wage that can be paid to unskilled workers. Whereas for Fleming this living labour becomes a species of unnecessary labour or artificial overemployment (2017:163), that is to say, if tasks can be performed without the use of living labour, such labour becomes surplus to requirements. For Fleming there is a tension between the intensification of labour and the manner in which work colonises many people's lives, what Graeber (2013) describes as 'bullshit jobs'. Such jobs coexist with austerity as well as with a surplus population that is extraneous to the requirements of capital. For Graeber (2013) 'bullshit' jobs are associated with the growth of administrative and pointless work, often found in the service sector. In this instance workers carry out tasks 'they secretly believe do not really need to be performed' (np). However, such practices not only impact upon service workers but also on many kinds of professional and managerial labour. There is an affinity here with neoliberalism, performativity and the surveillance of work, which has been facilitated by the growth of digital technologies allied to the requirement for on-going accountability. Such processes are compounded by the endless stream of meaningless emails (Fleming, 2017:137; Zukas and Malcolm, 2015). Glaser (2014), in a commentary on Graeber (2013), suggests,

Work that people find genuinely creative and meaningful... is now often supposed to be done unpaid. While technology has failed to liberate people into a life of leisure, it has succeeded in shunting non-bullshit work into non-work time (Glaser 2014: 88).

The academic labour process would be a case in point, but for many of those who work in education at a time of austerity, intensification and cost cutting, putative non-work time is frequently used to get the job done (Fleming, 2014: 1-2). The irony is that much of our actual work time is spent on 'busy' work necessitated by performative regimes of dubious value that keeps us occupied and saps our energy. Perhaps this is why Glaser (2014:83) states, 'a population that is busy and tired is less likely to revolt'. There is another aspect to such processes in which we may become fixated on the institutional and local where we can rail against the pointlessness of much that fills our working day (Avis and Reynolds, 2017).

Notions such as 'busy' work and 'bullshit' jobs draw our attention to the paradox of work. Waged labour is at the centre of the current doxa, being seen as pivotal to life and wellbeing. At the same time increasing numbers of people find themselves part of a surplus 
population that is no longer required by capital. Yet in recent years the amount of time spent in waged labour has increased and for many workers the distinction between life and work has been eroded (Srnicek and Williams, 2015: 115). This may appear paradoxical but can be seen as the way neo-liberal capitalism can "keep [us] all up to the mark" (Olssen, 2003: 200). Although capitalism celebrates waged labour, and "demands that people work in order to make a living, yet it is increasingly unable to generate enough [and we could add good] jobs" (Srnicek and Williams, 2015: 126). Low waged labour together with 'busy' work and 'bullshit' jobs become in effect a disciplinary strategy that locks us into the present. These debates seem very far from discussions of the $4^{\text {th }}$ IR as well as vocational education and training. However, they have some purchase on the way in which we think about the relationship between work and wider society and consequently pose questions for VET.

\section{Vocational Education and Training and the Fourth Industrial Revolution}

Frase (2016) in his book Four futures speculates on what life could be like after capitalism providing both optimistic and pessimistic narratives. What his book alerts us to is that there is nothing inevitable about the way in which social formations develop. Rather the direction they take will be the outcome of struggle as well as the balance of power between contending and antagonistic forces in society. This means the manner in which VET is framed within any particular society cannot be seen simply as a technical issue but is unavoidably intertwined with politics and the play of power.

Many consultants and policy reports that address the $4^{\text {th }}$ IR suggest that in an increasingly complex and interconnected world, characterised by the rapid development of technology and science it becomes self-evident that education and training should prepare us for this context. This is a context in which creativity, innovation, reflexivity, entrepreneurship, flexibility and adaptability are deemed to be pivotal, as are a range of soft skills (Daugherty and Wilson, 2018). These ideas are allied to a discourse in which learner engagement with STEM (science, technology, engineering and mathematics) subjects are essential - so far so good. Yet at the same time these notions encounter a series of contradictions. Frequently they are couched in terms of the development of human capital that belies the collective processes and accomplishments involved. They veer towards an individualised notion of a 'choice biography' whereby this becomes a project of the self, precluding the manner in which it is set within a wider structural context that features antagonistic relations between the interests of capital and labour (Ball, Maguire and Macrae, 2000; Du Bois-Reymond, 1998). Despite suggestions otherwise these notions are based upon a model of competitive individualism that belies this possibility in capitalist social formations. This arises from the consequence of job polarisation and hollowing out of middle level jobs.

We encounter a number of problems when we explore what, in the current conjuncture and one in which the imaginary of the $4^{\text {th }}$ IR is pervasive, a socially just and progressive VET curriculum would look like. 
- To what extent would it be socially and institutionally situated?

- How would it engage with the concerns of distributive justice - that is, in providing learners with resources to enable them to understand and critique the STEM and other disciplines that underpin their vocational practices (Wheelahan, 2010)?

- How would it provide access to what Young and others have referred to as powerful knowledge (McLean, Abbas, and Ashwin, 2017; Wheelahan, 2010; Young, 2008)?

- How would it articulate the relationship between powerful knowledge and the vernacular to develop 'really useful knowledge' (Avis, 2016:116-130; Education Group, 1981:37).

- How would it relate to wider society in developing an "ability to appreciate the broader economic and civic implications of occupational [and professional] action" (Winch, 2012:179).

- How would it contribute to the development of an engaged and critical citizenship in the pursuit of a socially just society (Avis 2016)?

These concerns go well beyond institutionally based expansive learning cultures of the type discussed by Fuller and Unwin (2003) and poses the question of the way in which we conceive the vocational. At the same time, it is tremendously important to address the pedagogic issues that concern the engagement of learners at all levels, regardless of age and employment status. These questions cannot be answered abstractly but need to be grounded in a politically and vocationally engaged praxis.

\section{By Way of Conclusion}

This paper has addressed a wide ranging literature set within the current conjuncture in which conceptualisations of the $4^{\text {th }}$ IR are pivotal. It has sought to address a number of important arguments and debates that bear upon the $4^{\text {th }} \mathrm{IR}$. It illustrates that the relationship between technology and skill is rather more complex than the more populist proponents of technological unemployment suggest. Thus, for example at the present time, interconnected and networked advanced manufacturing processes need to be monitored by highly skilled living labour. Labour economists would argue that to the extent that technological unemployment arises it is a frictional rather than structural issue. However, critical analyses and neo-Marxist discussions of the elimination of labour from paid employment, together with the falling rate of profit, bypass the former arguments. It is important to recognise that technology, digitalisation and artificial intelligence are entwined with social relations and consequently are sites of class struggle. How this is played out is an outcome of the balance of power, not only within the social formation but also globally. How far the development of the forces of production are compatible with capitalist relations is a moot point, as these are also a site of struggle. In addition, there are important questions about the way in which we conceptualise vocational education and training and its articulation to a socially just society. Such conceptualisations cannot be predetermined and need to be argued through and struggled over, as do the associated pedagogic 
practices. It is also important to recognise than many of the issues discussed in this paper cannot be resolved at the level of VET and necessitate the development of a non-reformist politics in pursuit of a socially just society, of the kind argued for by writers such as Fraser (2013) and Gorz (1968:7-8) who comments,

A struggle for non-reformist reforms - for anti-capitalist reforms - is one which does not base its validity and its rights to exist on capitalist needs, criteria, and rationales. A non-reformist reform is determined not in terms of what can be, but what should be.

\section{Acknowledgment}

I would like to thank Professors Gavin Moodie, Ann-Marie Bathmaker, Kevin Orr and Leesa Wheelahan for their helpful comments and suggestions on an earlier draft of this paper.

\section{References}

Acemoglu, D. Restrepo, P. 2017a. Robots and Jobs: Evidence from US Labor Markets. NBER Working Paper No. 23285. National Bureau of Economic Research. http://www.nber.org/papers/w23285.pdf

Acemoglu, D. Restrepo, P. 2017b. "Robots and Jobs: Evidence from the US". Vox, Centre for Economic Policy Research, https://voxeu.org/article/robots-and-jobs-evidence-us

Adam, B. Groves, C. 2007. Future matters: action, knowledge, ethics, London, Brill

Adler, P. (2006). From labor process to activity theory. In Sawchuk, P. H., Duarte, N. \& Elhammoumi, M. (eds), Critical Perspectives on Activity: Explorations Across Education, Work and Everyday Life, pp. 225-61. Cambridge: Cambridge University Press.

Adler, P. \& Heckscher, C. (2006). Towards collaborative community. In Heckscher, C. \& Adler, P. (eds), The Firm as a Collaborative Community, pp. 11-105. Oxford: Oxford University Press

Aigrain, P. 2012. Sharing: culture and economy in the internet age, Amsterdam, Amsterdam university press

Alhammadi, Y. Brynjolfsson, E. MacCrory, F. Westerman, G. 2014. Racing with and Against the Machine: Changes in Occupational Skill Composition in an Era of Rapid Technological Advance, Thirty Fifth International Conference on Information Systems, Auckland 2014 1-17 
Anderson, E. 2017. Reply to Commentators, Anderson, E. (ed) Private Government, Princeton, Princeton University Press,119-144.

Anslow, L. 2016. Robots have been about to take all the jobs for more than $\mathbf{2 0 0}$ years: Is it really different this time? https://timeline.com/robots-have-been-about-to-take-allthe-jobs-for-more-than-200-years-5c9c08a2f41d

Atkinson, R. Wu, J. 2017. False alarmism: technological disruption and the U.S. labor market, 1850-2015, Information Technology and Innovation Foundation, http://www2.itif.org/2017-false-alarmism-technologicaldisruption.pdf? ga=2.144641148.812496487.1496450124-341239608.1496450124

Autor, D. 2013. The Task Approach to Labor Markets: An Overview. Journal for Labour Market Research. 46(3) 185-99

Autor, D. 2015. Why Are There Still So Many Jobs? The History and Future of Workplace Automation, The Journal of Economic Perspectives, 29(3) 3-30

Autor, D. Katz, L. Kearney, M. 2006. The Polarization of the U.S. Labor Market, The American Economic Review, 96(2), 189-194

Autor, D., Levy, F., and Murnane, R. 2003. "The Skill Content of Recent Technological Change: An Empirical Exploration," The Quarterly Journal of Economics 118(4), 12791334

Avent, R. 2016. The wealth of humans, London, Penguin

Avis, J. 1981. Social and Technical Relations: The case of FE. In British Journal of Sociology of Education, 2:2, 145-161

Avis, J. 1993. Post-Fordism, Curriculum Modernisers and Radical Practice: the case of vocational education and training in England in The Vocational Aspects of Education Vol. 45, No1. 1993 p3-14

Avis, J. 2003. Work-based knowledge, evidence-informed practice and education. British Journal of Educational Studies, 51(4): 369-389.

Avis, J. 2016. Social Justice, Transformation and Knowledge: policy. workplace learning and skills, London, Routledge 
Avis, J., Reynolds, C. 2017. The digitalisation of work and social justice - reflections on the labour process of English Further Education (VET) teachers, Harteis, C. (ed) The impact of digitization in the workplace: An educational view Dordrecht, Springer series Professiona

Ball, S.J. Maguire, M. Macrae, S. 2000. Choice, Pathways and Transitions Post-16. London: RoutledgeFalmer.

Baxter, G. Rooksby, J. Wang. Y. Khajeh-Hosseini, A. 2012. The ironies of automation ... still going strong at 30? Proceedings of ECCE 2012 Conference, 29th-31st August, Edinburgh, North Britain, 65-71

Beckett, A. 2018 The Long Read: Post-work the radical idea of a world without jobs https://www.theguardian.com/news/2018/jan/19/post-work-the-radical-idea-of-a-worldwithout-jobs

Benkler, Y. (2006) The Wealth of Networks: How Social Production Transforms Markets and Freedom, London, Yale University Press

Blacker, D. 2013. The falling rate of learning and the neoliberal endgame, London, Zero books

Bloem, J. van Doorn, M. Duivestein, S. Excoffier, D. Maas, R. van Ommeren, E. 2014. The Fourth Industrial Revolution Things to Tighten the Link Between IT and OT, VINT research report 3, https://www.sogeti.com/explore/reports/vint-research-3-things--the-fourth-industrial-revolution/.The Fourth Industrial Revolution Things to Tighten the Link Between IT and OT, VINT research report 3, https://www.sogeti.com/explore/reports/vint-research-3-things---the-fourthindustrial-revolution/

Braverman, H. 1974. Labor and Monopoly Capital: The Degradation of Work in the Twentieth Century, New York, Monthly Review Press

Bregman, R. 2016. Utopia for Realists, Amsterdam, the correspondent https://thecorrespondent.com/

Bodrožić, Z. Adler, P. 2018. The Evolution of Management Models: A Neo-Schumpeterian Theory Administrative Science Quarterly, Vol. 63(1) 85-129 DOI: 10.1177/0001839217704811

Boutang, Y. M. 2011. Cognitive Capitalism. Cambridge: Polity. 
Brynjolfsson, E. and McAfee, A. 2011. Race against the machine: How the digital revolution is accelerating innovation, driving productivity, and irreversibly transforming employment and the economy. Lexington, MA, Digital Frontier Press

Brynjolfsson, E., McAfee, A., 2014. The Second Machine Age: Work, Progress and Prosperity in a Time of Brilliant Technologies. New York, Norton \& Company.

Carney, M. 2014. Inclusive Capitalism: Creating a Sense of the Systemic. Speech at the Conference on Inclusive Capitalism. Retrieved from www.bankofengland.co.uk/publications/ Documents/speeches/2014/speech731.pdf on 29 May 2014.

Chollet, F. 2017. The impossibility of intelligence explosion, Medium, https://medium.com/@francois.chollet/the-impossibility-of-intelligenceexplosion-5be4a9eda6ec

Citi GPS: Global Perspectives \& Solutions. 2016. Technology at Work v2.0: The Future Is Not What It Used to Be, https://www.oxfordmartin.ox.ac.uk/publications/view/2092

Cowen, T. 2017. Work isn't so bad after all, Anderson, E. (ed) Private Government, Princeton, Princeton University Press, 108-116

Coyle, D. 2017. Precarious and Productive Work in the digital economy, National Institute Economic Review No. 240 5-14

Davis, M. (2006) Planet of slums, London Verso

Dittrich, P. (2016) Reskilling for the Fourth Industrial Revolution: Formulating a European Strategy. Jacques Delors Institut - Berlin. http://www.institutdelors.eu/wpcontent/uploads/2018/01/digitalskill-jdib-nov2016.pdf?pdf=ok

Dolphin, T. (ed) 2015. Technology, Globalisation and the Future of Work in Europe: Essays On Employment In A Digitised Economy, London IPPR, https://www.ippr.org/publications/technology-globalisation-and-the-future-of-workin-europe

Daugherty, R., Wilson, H. 2018. Human + Machine: reimagining work in the age of Al, Boston Harvard business Review Press

Manuela Du Bois-Reymond (1998) ‘I Don't Want to Commit Myself Yet': Young People's Life Concepts, Journal of Youth Studies, 19(1) 63-79 
Education Group, CCCS (1981). Unpopular Education. London: Hutchinson.

Ehrenreich, B. 2002. Nickle and dimmed: undercover in low-wage USA. London, Granta

EPPI-Centre (n.d.). "What is a systematic review?

https://eppi.ioe.ac.uk/cms/Default.aspx?tabid=67

European Education Research Journal (forthcoming) Special Issue Vocational education, transitions, marginalisation and social justice in the Nordic countries Nyland, M. Rosvall, P-A (Eds)

Fleming, P. 2014. Resisting work. Philadelphia, Temple university press

Fleming, P. 2015. The mythology of work. London, Pluto

Fleming, P. 2017. The death of Homo Economicus, London, Pluto

Ford, M. (2016) The rise of the robots, London, Oneworld

Fraser, N. 2013. Fortunes of Feminism. London: Verso

Frayne, D. 2015. The refusal of work, London, Zed books

Frayssé, O. (2015) is the concept of rent relevant to a discussion of surplus-value in the digital world, in Fisher, E., Fuchs, C. (eds) Reconsidering Value and Labour in the Digital Age, Basingstoke, Palgrave MacMillan, 172-187

Frase, P. 2016. Four futures: Life after capitalism. London, Verso

Frey, C. Michael A. Osborne, M. (2013) The Future of Employment: how Susceptible are Jobs to Computerisation? Published by the Oxford Martin Programme on Technology and Employment, https://www.oxfordmartin.ox.ac.uk/publications/view/1314

Fuchs, C. 2018. Industry 4.0: the digital German ideology, tripleC, 16(1) 280-289

Fuller, A. and Unwin, L. 2003. Learning as apprentices in the contemporary UK workplace: creating and managing expansive and restrictive participation, Journal of Education and Work, 16(4) 407-426.

Glaser, E. 2014. Beyond bullshit jobs, Soundings, 57 p82-94 
Goodhart, C. Pradhan, M, 2017. Demographics will reverse three multi-decade global trends BIS Working Papers, No 656, Bank of International Settlements

Goos, M. Manning, A. (2007) Lousy and Lovely Jobs: The Rising Polarization of Work in Britain, The Review of Economics and Statistics, 89(1), 118-133

Goos, M. Manning, A. Salomons, A. 2014. Explaining Job Polarization, The American Economic Review, 104(8), 2509-2526

Gorz, A. 1968. Strategy for labour, Boston, Beacon Press

Gorz, A. 2010. The immaterial, London, Seagull

Graeber, D. 2013. On the phenomenon of Bullshit Jobs, Strike! magazine, http://strikemag.org/bullshit-jobs/ accessed 1 Sept 2014

Hajkowicz, S. Reeson, A. Rudd, L. Bratanova, A. Hodgers, L. Mason, C. Boughen, N. 2016 Tomorrow's Digitally Enabled Workforce: Megatrends and scenarios for jobs and employment in Australia over the coming twenty years https://publications.csiro.au/rpr/pub?pid=csiro:EP161054\&

Haldane, A. 2015 Labour's Share Speech given by Chief Economist, Bank of England https://www.bankofengland.co.uk/-/media/boe/files/speech/2015/laboursshare.pdf?la=en\&hash=D6F1A4C489DA855C8512FC41C02E014F8D683953

Harvey, D. 2014. Seventeen contradictions and the end of capitalism, London, Profile

Holzer, H. 2015. "Job Market Polarization and U.S. Worker Skills: A Tale of Two Middles." Brookings Institution Economic Studies Working Paper, https://www.brookings.edu/wpcontent/uploads/2016/06/polarization_jobs_policy_holzer.pdf

Hutton, W. (2010). Them and Us. London: Little Brown.

Hutton, W. (2015). How good we can be, London, Abacus

Jasanoff, S. 2015a. Future imperfect: science, technology and the imaginations of modernity, in Jasanoff, S. Kim, S-H. Eds. Dreamscapes of Modernity, Chicago, Chicago, University Press, 1-33 
Jasanoff, S. 2015b. Imagined and Invented worlds, in Jasanoff, S. Kim, S-H. Eds. Dreamscapes of Modernity, Chicago, Chicago, University Press, 321-341

Jasanoff, S. Kim, S-H. Eds. 2015. Dreamscapes of Modernity, Chicago, Chicago, University Press, 1-33

Kagermann, H. Wahlster, W. Helbig, J. 2013. Recommendations for implementing the strategic initiative INDUSTRIE 4.0, Securing the future of German manufacturing industry Final report of the Industrie 4.0 Working Group, http://www.acatech.de/fileadmin/user upload/Baumstruktur nach Website/Acatech $\angle$ root/de/Material fuer Sonderseiten/Industrie 4.0/Final report Industrie 4.0 acc essible.pdf

Keep, E. \& James, S. (2012) A Bermuda Triangle of Policy? 'Bad Jobs', Skills Policy and Incentives to Learn at the Bottom End of the Labour Market, Journal of Education Policy, 27(2), 211-230.

Kenworth, L. 2004. Egalitarian Capitalism, New York, Russell Sage Foundation

Keynes, J.M. (2009). Economic possibilities for our grandchildren (1930). Essays in persuasion, New York, Classic House books 191-202

Lagarde, C. (2014, 27 May). Economic Inclusion and Financial Integrity. Address to the Conference on Inclusive Capitalism, London. Retrieved from www.imf.org/external/np/speeches/2014/052714.htm on 29 May 2014.

Leadbeater, C. 1999. Living On Thin Air: A New Economy, London, Viking

Livesey, F. 2017. From global to local, London, profile books

Livingston, J. 2016. No more work. Chapel Hill, University of North Carolina Press

Lordon, F. 2014. Willing Slaves of Capital, London, Verso

Lotringer, S. (2004) foreword, in Virno, P. A Grammar of the Multitude, Los Angeles, Semiotext(e) 7-19

MacLure, M. 2005. 'Clarity bordering on stupidity': where's the quality in systematic review? Journal of Education Policy, 20(4) 393-412 
McLean, M., Abbas, A. and Ashwin, P. (2017) Quality in undergraduate education: how powerful knowledge disrupts inequality, London: Bloomsbury.

Marazzi, C. (2011). The Violence of Financial Capitalism. Los Angeles: Semiotext(e).

Martin, R., Morrison, P. S. (2003) The geographies of labour market inequality, in Martin, R., Morrison, P. S. (Eds) Geographies of Labour Market inequality, London, Routledge.

Marx, K. 1976. Capital: a critique of political economy, Vol 1, Harmondsworth, Penguin

Mason, P. 2015. Postcapitalism, London, Allen Lane

May, T. 2016. keynote speech Delivered to the Conservative conference in Birmingham http://www.independent.co.uk/news/uk/politics/theresa-may-speech-tory-conference-2016in-full-transcript-a7346171.html accessed 5 Oct 2016

Mazzucato, M. 2013. The Entrepreneurial State: debunking private vs. public sector myths, London: Anthem Press.

Mazzucato, M. Perez, C. 2014. Innovation as Growth'Policy: the challenge for Europe. Working Paper Series, Science Policy Research Unit, The University of Sussex, SWPS 2014- 3

McAfee, A. Brynjolfsson, E. 2017. Machine Platform Crowd, New York, Norton

MGI. 2013. Disruptive technologies: Advances that will transform life, business, and the global economy. Tech. Rep., McKinsey Global Institute. https://www.mckinsey.com/business-functions/digital-mckinsey/ourinsights/disruptive-technologies

MGI. 2017. A Future that Works: Automation, Employment, and Productivity https://www.mckinsey.com/ /media/McKinsey/Global\%20Themes/Digital\%20Disrupti on/Harnessing\%20automation\%20for\%20a\%20future\%20that\%20works/MGI-Afuture-that-works-Executive-summary.ashx

Miliband, R. 1973. The State in Capitalist Societies. London: Quartet.

Mishel, L. Bivens, J. 2017. The zombie robot argument lurches on, Economic Policy Institute, http://www.epi.org/publication/the-zombie-robot-argument-lurches-onthere-is-no-evidence-that-automation-leads-to-joblessness-orinequality/?utm content=buffereba76\&utm medium=social\&utm source=twitter.c om\&utm campaign=buffer 
Mishel, Lawrence, and Heidi Shierholz. 2017. Robots, or Automation, Are Not the Problem: Too Little Worker Power Is. Economic Policy Institute.

https://www.epi.org/publication/robots-or-automation-are-not-the-problem-toolittle-worker-power-is/

Mokyr, J. Vickers, C. Ziebarth, N. 2015. The History of Technological Anxiety and the Future of Economic Growth: Is This Time Different? Journal of Economic Perspectives 29(3) 31-50

Moodie, G. 2016. Universities, disruptive technologies, and continuity in higher education: the impact of information revolutions, Palgrave Macmillan, New York.

Mowery, D.C. (2010) 'Military R\&D and innovation.' In Handbook of the Economics of Innovation, Vol 2Hall, B.H. and Rosenberg, N. (eds.) Chapter 29. Amsterdam: NorthHolland. 1219-1256

N8 Research Partnership. (2016). Driving Productivity Growth Through Innovation in High Value Manufacturing. Retrieved from https://www.n8research.org.uk/economicimpact/northern-powerhouse/driving-productivity-growth-innovation-high-valuemanufacturing/.

Nevin, S. 2016. Lifelong Learning Reforming education for an age of technological and demographic. IoD policy report, https://www.iod.com/Portals/0/PDFs/Campaigns\%20and\%20Reports/Employment\%2 0and\%20Skills/Life\%20Long\%20Learning\%20Report.pdf?ver=2016-09-14-124014-230

Orr, K. (2016) "Who cares about vocational education and training? Pedagogy and pathways for the 'overlooked middle'"' inaugural lecture, The University of Huddersfield, $1^{\text {st }}$ December

Oschinski, M. Wyonch, R. 2017. Future Shock? The impact of automation on Canada's labour market, C D Howe Institute commentary number 472, https://www.cdhowe.org/public-policy-research/future-shock-impactautomation-canadas-labour-market

Peters, M. A. 2017. Technological unemployment: Educating for the fourth industrial revolution, Educational Philosophy and Theory, 49(1), 1-6 DOI:

10.1080/00131857.2016.1177412 
Pew Research Centre. 2017. The future of jobs and jobs training, http://www.pewinternet.org/2017/05/03/the-future-of-jobs-and-jobs-training/

Pfeiffer, S. 2014. Digital Labour and the Use-value of Human Work. On the Importance of Labouring Capacity for Understanding Digital Capitalism tripleC 12(2): 599-619,

Pfeiffer, S. 2016. Robots, Industry 4.0 and Humans, or Why Assembly Work Is More than Routine Work, Societies, Societies, June, 1-26 doi:10.3390/soc6020016

Pfeiffer, S. 2017. The Vision of "Industrie 4.0" in the Making - a Case of Future Told, Tamed, and Traded, Nanoethics 11:107-121, DOI 10.1007/s11569-016-0280-3

Poulantzas, N. (1978). State, Power, Socialism. London: New Left Books.

Roberts, K. (2016) Youth cultures and the formation of a new political generation in Eastern Europe, in Schwartz, M., Winkel, H. (Eds) Eastern European Youth Cultures in a Global Context, London, Palgrave, pp46-63

Rodrik, D. 2016. Premature deindustrialization. Journal of Economic Growth 2(1) 1-33

Roediger, D. 2017. Class, race, and Marxism, London, Verso

Riffkin, J. 1995. The end of work, New York, Putnam

Riffkin, J. 2014. The zero marginal cost society, London, Palgrave MacMillan

Ross, A. 2016. The Industries of the future, London, Simon \&Schuster

Sainsbury, D. 2013. Progressive Capitalism. London: Biteback Publishing.Schwab, K. 2017. The Fourth Industrial Revolution, London, Portfolio Penguin

Sale, K. 1996. Rebels against the future, New York, Addison-Wesley

Saniter, A., Howe, F. 2017. Industry 4.0 - what's behind the mask? A case of addititve manufacturing In Kaiser, F., Krugmann, S. (Eds) Social dimensions and participation in Vocational Education, University of Rostock, Rostock 172-176

Sassen, S. 2014. Expulsions, Harvard, Harvard University Press 
Schrauf, S. Berttram, P. 2016. Industry 4.0: How digitization makes the supply chain more efficient, agile, and customer-focused, PWC, https://www.strategyand.pwc.com/reports/digitization-more-efficient

Seeverband der Bayerischen Metall und Elektro-Arbeitsgeber. 2016. Industrie 4.0Auswirkungen auf Asund Weiterbildung in der M+E Industrie, https://www.vmenet.de/sites/default/files/downloads_und_vorschaubilder/baymevbm_studie_industri e-4-0.pdf

Selwyn, N. 2014. Digital Technology and the contemporary university, London, Routledge

Sennett, R. 2009. The Craftsman, Harmondsworth, Penguin

Shildrick, T., MacDonald, R., Webster, C., Garthwaite, K. (2012) Poverty and Insecurity: Life in low-pay, No-pay Britain, Bristol, Policy Press

Srnicek, N. 2017. platform capitalism, Cambridge, Polity

Srnicek, N., Williams, A. 2015. Inventing the future: postcapitalism and a world without work, London, Verso

Standing, G. 2016. The corruption of capitalism, London, Biteback

Streek, W. 2016. How will capitalism end? London, Verso

Susskind, R. Susskind, D. 2015. The future of the professions, Oxford, Oxford University Press

Tegmark, M. 2017. Life 3.0, London, Allen Lane

Thelen, K. (2014) Varieties of liberalization and the new politics of social solidarity, New York, Cambridge University Press

Thelen, K. and Busemeyer, M. (2008) From collectivism towards segmentalism: Institutional change in German vocational training, MPIFG discussion paper 08/13, Coln, MaxPlanck-institute

Thelen, K. and Busemeyer, M. (2011). Institutional change in German vocational training: from collectivism towards segmentalism, in M. Busemeyer and C. Trampusch (eds) The political economy of collective skill formation, (pp.68-100). Oxford: Oxford University Press. 
Teixeira, R. 2017, It's time to explode the myth of "McJobs", https://www.vox.com/thebig-idea/2017/6/13/15788610/robots-artificial-intelligence-ai-mcjobs-low-skill

Tronti, M. (2007) The strategy of refusal in Lotringer, S., \& Marazzi, C. (Eds) Autonomia, Los Angeles, Semiotext(e) 28-35

Wahlster, W. 2016. Industrie4.0: Cyber-Physical Production Systems for Mass Customization, German-Czech Workshop on Industrie4.0/Průmysl 4.0, Prague, April 11, http://docplayer.net/40256809-Industrie-4-0-cyber-physical-production-systemsfor-mass-customization.html

Wallerstein, I. Collins, R. Mann, M. Derluguian, G. Calhoun, C. 2013. Does Capitalism have future? Oxford, Oxford university press

Weeks, K. 2011. The problem with work, Durham, Duke University Press

Weil, D. 2014. The fissured workplace, Cambridge, Harvard University Press Wilkinson, R. \& Pickett, K. (2010). The Spirit Level: Why Equality is Better for Everyone. Harmondsworth: Penguin.

Wheelahan, L. (2010). Why Knowledge Matters in Curriculum. London: Routledge

Whittaker, M. 2015. What do Current Trends tell us about the British Labour Market of Tomorrow? In Dolphin, T. (ed) 2015. Technology, Globalisation and the Future of Work in Europe: Essays On Employment In A Digitised Economy, London IPPR, 36-41 https://www.ippr.org/publications/technology-globalisation-and-the-future-of-workin-europe

Wilkinson, R. \& Pickett, K. (2010). The Spirit Level: Why Equality is Better for Everyone. Harmondsworth: Penguin.

Winch, C. (2012). Dimensions of Expertise. London: Continuum.

Young, M. (2008). Bringing Knowledge Back In. London: Routledge

YouTube. 2014. Australians for coal. https://www.youtube.com/watch?v=tqXzAUaTUSc

Zukas, M., Malcolm, J. (2015) Learning to be a social scientist, paper presented RWL9 $-9^{\text {th }}$ International Conference on researching Work and Learning, Singapore 9-11 December 
Figure 1. Industrial Revolutions

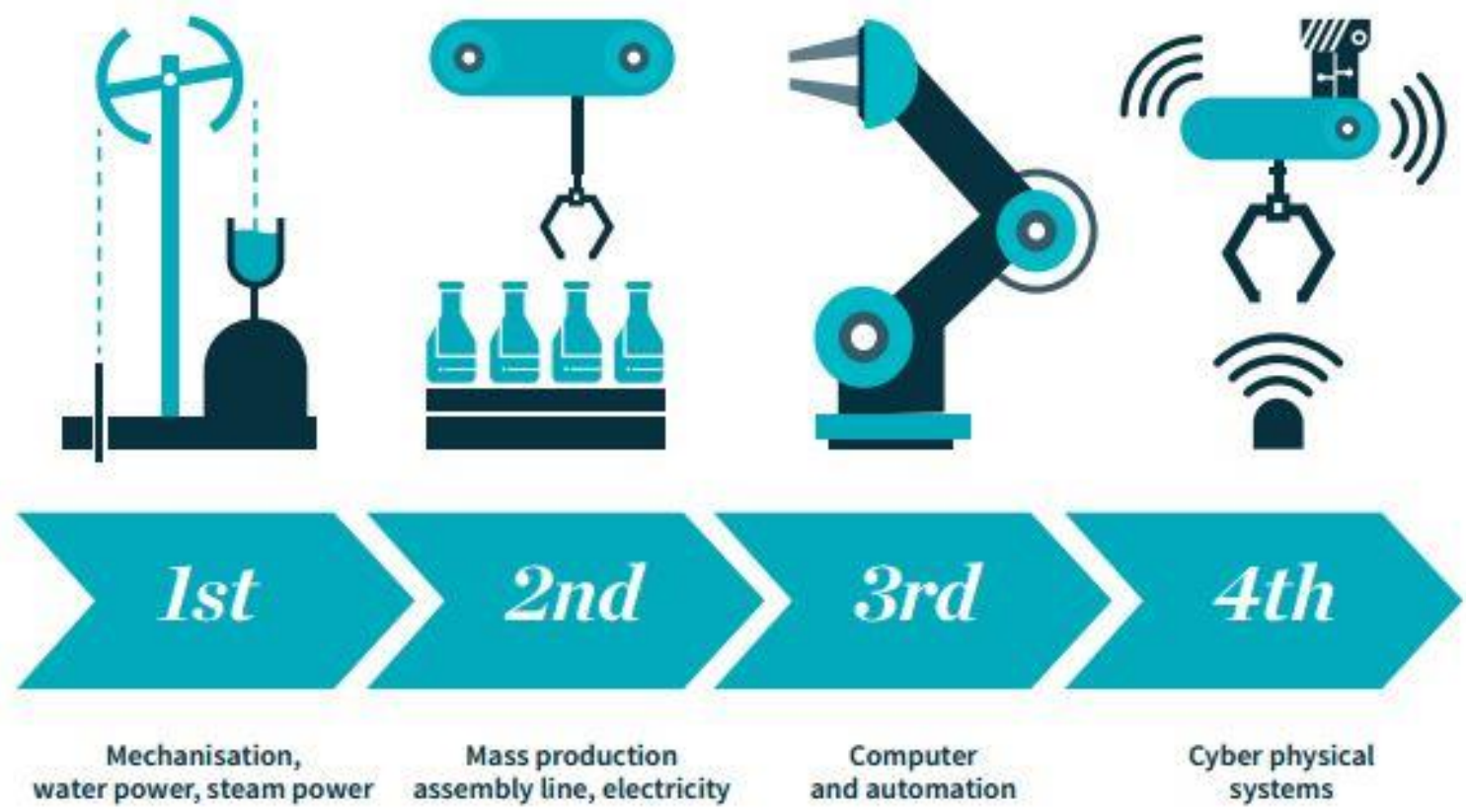

source: N8 Research Partnership, 2016 